\title{
ALEXANDER, HANNIBAL, AND SCIPIO IN LUCIAN
}

Not much has been written about this particular Dialogue of the Dead. What there is, apart from noting the obvious fact of it being a comic syncrisis, concentrates on the role of Scipio and Lucian's alleged historical errors throughout the piece. But there is much more to be said about correlation of satire and history in the piece, and the supposed historical errors melt away upon examination. This paper also encompasses two new topics: a general review of the dialogue and its theme in terms of both genre and topicality, and some possible internal evidence for redating it to a later period than has hitherto been done.

In Lucian's twenty-fifth' Dialogue of the Dead, Alexander the Great and Hannibal enter quarrelling over who was the better general. At the former's suggestion, Minos arbitrates their dispute. With Hannibal going first, both plead their cases, each man's speech combining self-advertisement and denigration of the other. As Alexander is concluding his, Scipio bursts in and asks that he too be heard, a request granted by Minos. The Roman presents his case in three economical sentences, asserting that he is a lesser man than Alexander (praised as incomparable) but greater than Hannibal. Minos agrees and takes over Scipio's conclusion as his own, adding the tactful footnote that Hannibal, though third, is not to be despised.

Not a lot has been written about this piece. Editors and commentators have duly noted the obvious fact that it is a comic syncrisis inspired by the anecdote of Scipio's conversation with Hannibal at Ephesus in 193 retailed by Livy, Plutarch, and Appian, but without going into any detailed textual syncrisis of their own. One or two details, notably the role of Scipio and Lucian's supposed capacity for getting historical details wrong, have attracted some comment. But there is more to be said about the first matter, and most of what little has been

I In the enumeration of M. D. Macleod's 1987 OCT, also that of his 1961 Loeb; it is no. 12 in the traditional sequence. 
written about the second is deficient. Two fresh topics can be incorporated, namely possible internal evidence for redating the dialogue a good deal later than has hitherto been done, and a general review of the topicality of the subject and the genre along with their exploitation for serious or comic purposes in other contemporary and later authors.

As recounted by Livy ${ }^{2}$ (XXXV 14, 1-9), Scipio asked Hannibal whom he thought to be the greatest general. Hannibal replied that Alexander was, because of his defeats of huge enemy armies with a small force and because (to adapt the famous Star Trek prologue) he had boldly gone where no man had gone before. Scipio accepted this without comment, going on to ask who would come second. Hannibal gives this spot to Pyrrhus because he was the pioneer of castrametation, subjoining his skills in winning the Italians over to his cause. When Scipio enquired whom Hannibal would rank third, the latter gave that honour to himself "without hesitation" (or, we may add, reason). With a wry laugh, the former asked what Hannibal would have said if he himself had defeated Scipio. Hannibal responded at once that he would in that case have put himself first, before Alexander, Pyrrhus, and all others, a well-judged and typically Punic surprise answer (perplexum Punico astu responsum et improuisum).

Appian (Syr. 10) has the same basic story, albeit with some difference of details. Alexander's first place is neither justified nor queried. Pyrrhus is given the second on the sole basis of his Alexander-like boldness, a reply that rather irks Scipio. Hannibal's selection of himself for the third spot is justified at some length: crossing the Alps, invading and ravaging Italy to the tune of four hundred cities, and putting Rome herself in jeopardy - all without help from his native Carthage. In the balance of the story (which follows Livy), Appian adds that Hannibal flattered Scipio as he did to assuage the Roman's blatant jealousy. Appian also improves the shining hour by adding a postscript to the conversation detailing the reconciliation between Hannibal and Scipio, their magnanimity being obtrusively contrasted with the mean-mindedness of Flamininus who is condemned for hounding Hannibal to his death.

This latter point is also tackled by Plutarch (Flam. XXI 1-6) who uses it as both prologue and epilogue to his version, concluding with a justification of Flamininus' actions. The biographer's account of the Hannibal-Scipio conversation is very brief, being encompassed in a sin-

${ }^{2}$ Cf. the commentary of J. Briscoe, Oxford 1981, pp. 165-7, for Livy's sources and the historicity (much debated) of the tale. 
gle sentence with no reasons offered for the assignment of first, second, or third places, and with Scipio amused rather than upset by Hannibal's responses.

Plutarch's urisk version ${ }^{3}$ of the anecdote is fair enough; it is after all Flamininus who is his principal subject. The biographer, however, returns to the matter at Pyrrhus VIII 1-3, a passage which in view of its different approach has clearly been more cited than read by some observers. Anderson ${ }^{4}$ lists it along with Livy as though it were the same story, neglecting both the Flamininus version and that of Appian. It is worth adding, in view of Anderson's general playing-down of Lucian's topicality, that Appian appears nowhere in his index of proper names. Macleod likewise does not discriminate in his register of references, something that could have been achieved even within the cramped confines of an $O C T^{5}$. As for Bompaire ${ }^{6}$, he notices neither of the Plutarch passages nor Appian!

In this second version, Plutarch begins with Macedonian comparisons of Pyrrhus to Alexander, adding that Antigonus, when asking who was the best general, replied "Pyrrhus, if he lives to be old". But the biographer promptly subjoins that Antigonus was speaking only of contemporaries. He goes on to refer to his own lost Life of Scipio ${ }^{7}$ in which Hannibal put himself third to Pyrrhus and Scipio. No reasons are offered for this pecking order. Plutarch again achieves the comparison in a single sentence, being here doubly justified in so doing, since Pyrrhus not Hannibal is his subject and he has provided a cross-reference to the (clearly detailed) version in his Life of Scipio. Hannibal's

${ }^{3}$ See later for Lucian's quick use of the story at $\mathrm{VH}$ II 9.

4 G. Anderson, Lucian: Theme and Variation in the Second Sophistic, Leiden 1976, p. 98 , n. 63.

5 His Loeb note is more helpful; cf. the notes of H. L. Levy contained in his Lucian: Seventy Dialogues, Norman, Oklahoma, 1976, pp. 227-32, not noticing the Pyrrhus passage and very misleadingly dismissing Scipio as «a mere Roman in this Hellenocentric milieu".

6 J. Bompaire, Lucien Ecrivain, Paris 1958, p. 189, n. 6.

7 Not too much need here be said about the well-known problem of which Scipio's Life formed part of the lost pair with Epaminondas; for a convenient summary of the issue with bibliography, see H. H. Scullard, Scipio Africanus: Soldier and Politician, London 1970 , p. 248, n. 15 . It seems clear from the present passage and from allusions at Tib. Grach. XXI 9 and C. Gracch. X 5 that Plutarch wrote biographies of both Scipios, though in theory material about Africanus could have been included in a life of Aemilianus. I rather think that Appian's comparison (Syr. 41) between Africanus and Epaminondas suggests that these two formed Plutarch's pair (having come to this conclusion, I subsequently found the connection had been made by $D$. A. Russell, Plutarch, London 1973, p. 113, n. 26); cf. A. E. Astin, Scipio Aemilianus, Oxford 1967, p. 1, n. 3. 
failure to mention Alexander is, of course, striking. So is (in terms of Lucian's comic treatment) Plutarch's subsidiary anecdote in which, when asked whether Python or Caphisias was the better flute player, Pyrrhus replied that Polysperchon was a good general, the implication being that kings and generals compared only themselves.

Clearly, Lucian had a range of treatments ${ }^{8}$ available to him. Of subsidiary importance to the general theme are the accounts of that other great meeting between Hannibal and Scipio, namely the one before Zama retailed by Livy (XXX 30-1) where the two men are admiratione mutua prope attoniti and where they confine their comparisons to each other - neither man drags in Alexander or Pyrrhus. Livy, however, editorialises to the effect that the two men were non suae modo aetatis maximi duces, sed omnis ante se memoriae, omnium gentium cuilibet regum imperatorumue pares. Livy's account is substantially that of Polybius (XV 6-8), except that the Greek historian does not talk of mutual admiration and does not indulge in the blanket comparisons of the Roman, merely saying that Hannibal greeted Scipio before speaking first. Cornelius Nepos (Hann. 6) alludes to this meeting, and it is a fair supposition that Plutarch will have worked up a dramatic account in his Life of Scipio. Elsewhere (X 2), it should be added, Polybius strikes a characteristically offbeat note by comparing Scipio to the Spartan Lycurgus. It is a strained effort; although he concentrates on their characters and principles, the comparison is ultimately pointless. Is there some implied comment here on the inanity of standard syncriseis? As to Lycurgus, one recalls Lucian's good joke (Anach. 39) where Anacharsis asks sardonically if the Spartan waited to introduce his disciplinary regulations until he himself was safely past the age for flogging!

In Lucian's dialogue, for obvious comic purposes, Alexander and Hannibal have only contempt for each other. They confidently base their arguments on their own merits; neither adduces Pyrrhus or any other third party. Hannibal in Lucian begins with a series of boasts that largely parallel those in Appian: the conquest of Spain, crossing the Alps, ravaging Italy, and threatening Rome. However, whereas Appian makes Hannibal go on to add that he achieved all this without help from home, Lucian has him subjoin that he did all this without help from any divinity from Ammon, an obvious joke to make against Alexander but in its positioning one which suggests a recognisably comic departure from the Appian version, or others like it. Lucian might have

- It was absurd of J. Schwartz, Biographie de Lucien de Samosate, Brussels-Berchem 1965, p. 69, to restrict Lucian's sources to "peut-être Plutarque». 
had Appian directly in mind, though other (lost) Greek treatments, most obviously Plutarch's, could have contributed.

On balance, though neither is sparing with his insults, Hannibal is the more aggressive. Alexander has more to say about his own achievements than the shortcomings of his rhetorical opponent. Without suggesting that Lucian must have read Livy ${ }^{9}$, it can still be observed that Alexander's criticisms of Hannibal are Livian, or at least Roman. For easy example, the claim that Hannibal's Italian conquest were the fruits of knavery asnd deceit rather than honest warfare obviously smacks of Punica fides, whilst the specific charge that Hannibal lost the war through debauchery at Capua is reminiscent of the Livian epigram (XXIII 49) Capuam Hannibali Cannas ${ }^{10}$. Lucian also makes both men boast that they conquered large forces with small ones; in Livy, that is the first compliment Hannibal pays to Alexander. One other detail worth appending here is Alexander's claim that Hannibal deserved his ultimate fate at the court of Prusias, a predictable point but one that consorts with the above-mentioned defence of Flamininus made by Plutarch against unnamed detractors.

Although it may be going too far to claim that one can trace specific statements to specific sources, it is obvious enough that Lucian, who elsewhere ( $V H$ II 9 ) has a brisk version in which Rhadamanthus judges Hannibal to be second to Alexander without any intervention by Scipio or Pyrrhus, has created his comedy out of material familiar to himself and his audience from their mutual education and reading. As Appian's elaboration of the story shows, it was a theme of continuing interest. Aulus Gellius (NA VI 1, 1-5) reviews ancient Lives of Scipio in which the famous tale of Olympias and the serpent is also recounted of the Roman's mother; Hannibal's mockery in Lucian of the dreams of Olympias looks like a crack against this sort of attempt to equip Roman heroes with fake divine pedigrees. Gellius himself (IV 18) composed a notice of Scipio's defeat of Hannibal in the context of the hero defending himself against charges of corruption, a story that receives some space in Appian (Syr. 40); he also (III 4, 1) studied biographies by unspecified authors of Scipio Aemilianus. Fronto (p. 122, $22-123,1$

9 Though there is no reason to suppose Lucian's Latin less competent than of Plutarch who quotes Livy by name more than once in the pertinent narratives of Marcellus in S. Italy (Marc. XXIV 4, XXX 4), albeit C. P. Jones, Plutarch and Rome, Oxford 1971, pp. 68-70, 77, minimises the biographer's actual use of Livy.

${ }_{10}$ Neither Macleod nor Levy adduce any Greek sources for the item. It is worth adding that Livy (IX 18, 1) emphasises the corruption of Macedonian morality by Alexander's adoption of Persian customs; cf. later for a pertinent and contemporary application of such moralising exempla in Fronto. 
Van Den Hout = Haines, II 148) compares the qualities of Verus to the duritia of Hannibal and the disciplina of Scipio in the context of purging his soldiers of the immoral effects of their sojourn at Antioch, whilst in his De bello Parthico 8 (p. 209, $15-22$ Van Den Hout = Haines II, 28) the respective achievements and behaviour of Hannibal after Cannae and Scipio after Zama are compared.

Lucian's comic location of Hades for the generals' debate, with his customary poignant undertones of the brevity of life and vanity of ambition, is very much in keeping with the reflections of Marcus Aurelius at Medit. IV 33 where the ephemerality of Roman heroes both Republican and imperial is dwelt upon. Marcus runs a large gamut of exempla, from Camillus, Caeso, Volesus (sic) and Dentatus to Scipio and Cato (which ones are unspecified, but the elder pair look likely) to Augustus, Hadrian, and Pius. Again, there is no need to postulate that Lucian had Marcus Aurelius in mind or Marcus Lucian. But there is a point to be made: Lucian's humour is not gratuitous but part of a continuing tradition of treatments of the question of how to quantify military achievement and what the point of it all is.

Such comparisons naturally provided themes for declamations ${ }^{11}$. No doubt more for Roman students than for Greek ones. Scipio triumphing over Hannibal appears in a list of topics provided by the elder Seneca (Contr. VII 2, 7), whereas neither name occurs in the VS of Philostratus. But Roman history was, of course, available in Greek. It is suggestive that some Hellenes of the Roman period make defensive or pejorative allusions to Roman nomenclature, for easy instance Dio Chrysostom (Or. XXI 11) and Apollonius of Tyana (VA IV 5). Plutarch provides the obvious focus: his parallel treatments of Greeks and Romans were intended both for Greek and Roman readers and helped to cross cultural (if not always linguistic) barriers. The process was already in train; one thinks easily of the debate in Livy (IX 17-9) as to whether Alexander would have beaten the Romans had he lived to confront them. Lucian, who has his own comic version of this (Alexander tells Hannibal he couldn't be bothered to attack the West since it was already cowering in fear of him), continues Plutarch's good work in his own distinctive vein; it is worth repeating in the present connection the significant fact that the satirist is the first Greek to refer to all the inhabitants of the Roman Empire as «us» ${ }^{12}$.

"Cf. the useful survey by Anderson, p. 171.

12 A point well made by C. P. Jones, Culture and Society in Lucian, Cambridge, Mass., \& London 1986, p. 89. This admirable book should be read along with B. 
Livy's reflections (it may be added) are on his own introductory admission a rhetorical digression. Some points of similarity with Lucian's Dialogue have already been cautiously noted. It is worth stressing that Livy does not here speculate on whether Hannibal or Scipio or anyone else from a different age could have defeated Alexander; he confines himself to a list of Roman commanders of the time with whom Alexander would actually have had to engage, an approach similar to that of Antigonus in Plutarch earlier noted. Livy's seminar should, however, be kept in play as an elaborate example of syncrisis, involving (in the Polybian manner) a comparison of nations as well as individuals.

Exploitation of these time-honoured comparisons, serious and comic alike, continued after the age of Lucian. That of Julian's Caesares has often been noted ${ }^{13}$. Not so a sequence in the Historia Augusta, in the Life of Pescennius Niger (XI 3 - XII 2), the «literary" pedigree of which can be elucidated from what we have here. Pescennius only tolerated stories de Hannibale ceterisque talibus. He told a would-be panegyricist, scribe laudes Marii uel Hannibalis uel cuiusue ducis optimi uita functi... nam uiuentes laudare inrisio est. The biographer goes on to enumerate Pescennius' favourite exempla: imperial ones were Augustus, Vespasian, Titus, Trajan, Pius, and Marcus Aurelius; the Republican ones included Marius, Camillus, Quinctius (i.e. Cincinnatus), and Coriolanus. And when specifically asked about the Scipios, Pescennius denigrated them as felices magis quam fortes ${ }^{14}$.

An aspect of Lucian's Dialogue that has received some special attention is the sudden epiphany and brief speech of Scipio. Bompaire ${ }^{15}$ made little of him, whereas Anderson ${ }^{16}$ revives the notion of Ledergerber ${ }^{17}$ that we are supposed to think of the poetic agon in Aristo-

Baldwin Studies in Lucian, Toronto 1973, for insistence on the topicality of much of Lucian's satire against the more literary interpretations of Anderson and Bompaire.

${ }^{13}$ See Anderson, p. 171, along with B. Baldwin, "The Caesares of Julian", Klio 60,1978 , pp. 449-65. Anderson may be a little severe in dismissing the piece as "uninspired" but it was certainly overpraised by Gibbon when he called it "One of the most agreeable and instructive productions of ancient wit".

14 This exposition may serve to fortify $R$. Syme's discussions of the HA's treatment of Pescennius Niger in his Ammianus and the Historia Augusta, Oxford 1968, pp. 134-6, and Emperors and Biography, Oxford 1971, pp. 60-6. It is worth noticing the trick of style whereby the biographer lists the exemplary emperors in forward chronological sequence and his Republican models in backwards order.

is "Scipion joue un rôle insignificant aux côtés de l'arbitre Minos» (p. 290); cf. p. 189: "Scipion, inséparable d'Hannibal pour les besoins de la syncrisis".

16 P. 98, n. 59.

17 P. Ledergerber, Lukian und die altattische Komödie, diss. Fribourg-en-Suisse 1905, p. 49. 
phanes' Frogs, with Scipio substituting for Sophocles, a notion rightly scouted by Bompaire. After all, one could just as easily say that Scipio's intervention is a comic use of the symposiac motif of the late arrival ${ }^{18}$. Later on (172), Anderson regards such ex abrupto appearances as a Lucianic speciality. If so, it is one appropriated by Julian with his sudden introduction (Caes. $336 \mathrm{a}-\mathrm{b}$ ) of Pleasure and Jesus.

But what Lucian is really doing, on the literary level, is to bring Scipio into the debate exactly along the lines of his sudden question to Hannibal in Livy, Plutarch, and Appian. And other aspects can be considered. There was nothing new in comparing Romans with Alexander, either in the style of Livy's excursus or the unnamed flatterers mentioned by Plutarch (Pomp. XLVI 1); the biographer criticises this crew for forcing historical parallels to the point of inaccuracy in their comparisons of the Roman great man ${ }^{19}$ with the Macedonian. Scipio's quick appearance and victory over Hannibal would be, and was surely intended to be, congenial to his Roman audiences, whilst leaving the palm to Alexander would keep his Greek readers happy. By leaving Hannibal as "not inconsiderable», Lucian retains common sense, and the Carthaginian's third place finish is where he ended up in the other versions.

It is just possible (not more) that one passage in the Dialogue may help to date it. Hannibal deprecates the conquest of Alexander as merely over fugitive Medes and Armenians, in contrast to his own hard-won victories over Spain, the Gauls, and Italy. In his retort, Alexander does not challenge Hannibal on the point either by inflating the value of his Eastern enemies or by denigrating that of Hannibal's Western foes (albeit he does claim to have intimidated the Italians of his own day by his reputation). Hannibal's victories are mocked not by belittling Western qualities but by alleging that the Carthaginian scored them by Punica fides rather than military skill. It is conceivable ${ }^{20}$ that Lucian here intends a contrast between the Parthian victories of Verus and the northern campaigns with concomitant defence of Italy on the part of

18 A notion taken to extremes in the case of Habinnas in Petronius, Sat. 65, 3, by Averil Cameron, «Petronius and Plato», $C Q 19,1969$, pp. 367-70.

${ }^{19} \mathrm{Cf}$. Julian, Caes. 323 a, where the Scipios, Marius, and Camillus are compared favourably to Pompey.

${ }^{20}$ Obviously not provable, given the frequenoy of such moralising clichés; Livy's exploitation of it at IX 18, 1 (cf. n. 10 above) is again worth mentioning. On this passage in Livy, see H. R. Breitenbach, "Der Alexanderexkurs bei Livius», $M H 26$, 1969, pp. 147-8, as well as P. Green, "Caesar and Alexander: Aemulatio, Imitatio, Comparation, AJAH 3, 1978, pp. 1-26. 
Marcus Aurelius. This would be in obvious tandem with Lucian's celebrated ridicule of the historians of Verus' Parthica in his De historia conscribenda; Necyomanteia 10 is also adducible for an apparent and slighting allusion to Verus' wars. The notion might also give extra point to his introduction of Scipio, a Roman hero from the Roman past, into the Dialogue. On this interpretation, the Dialogue would go into the 170s, Schwartz, by contrast, assigned the Dialogues of the Dead as a group to either side of 159 in his chronological table (149), adding elsewhere (135; cf. 50-64) that «la contestation entre Alexandre et Hannibal ( VH II 9 - not II 19, as Schwartz has it) est postérieure au Dial. mort. $12 \%$. But none of this has any basis in fact, being confessedly based on a supposed thematic chronology largely owed to Helm ${ }^{21}$.

Finally, three details in Lucian's Dialogue where Macleod (in his Loeb notes) accuses him of error. First, Hannibal's statement that since

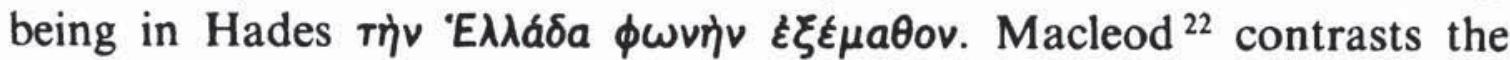
mention by Nepos (Hann. XIII 2) that the Carthaginian had written several books in Greek. It will also be remembered that in their preZama meeting both generals brought interpreters with them. But the point of Lucian's verb is that Hannibal had had time in Hades to perfect his Greek ${ }^{23}$, not to learn it from scratch. Moreover, Lucian's phraseology is pretty well identical with Herodotus II 154 on the specific matters of learning Greek and interpreters.

Secondly, both Macleod and Levy think Lucian in error when he makes Hannibal refer to his brother Hasdrubal, since in fact it was his brother-in-law under whom he served in Spain. Macleod thought that the satirist might be using the noun $\alpha \delta \varepsilon \lambda \phi \sigma \varsigma$ "very loosely". This is surely the explanation; a glance at $L S J$ (similar flexible uses of Latin words denoting kin will also be remembered) suggests that it can be embraced confidently rather than hesitantly.

Third, last, and biggest, Macleod fastens upon Scipio's self-descrip-

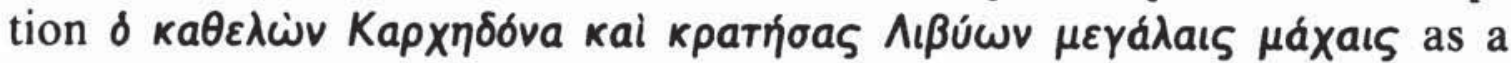
sign that Lucian has confused Scipio Africanus with Aemilianus; Levy was likewise worried. But this verb can be used of destroying the power of a city or person; Herodotus I 71 provides a parallel, in the context of Croesus hoping to bring down Cyrus and Persian power. And Macleod's concomitant translation of $\mu \varepsilon \gamma a$ גaıs $\mu a ́ x a ı s$ as «mighty battle»

${ }^{21}$ R. Helm, Lukian und Menipp, Leipzig 1906, p. 207.

${ }^{22}$ P. 145 , n. 2, in his Loeb.

${ }^{23}$ Hannibal himself later refines the point when he says that he had not had a chance on earth to study Homer under Aristotle and so acquire full Greek paideia. 
does Lucian no service. The plural does not suit the Third Punic War; it just as obviously does fit the Second. Lucian knew whereof he was writing! ${ }^{24}$

BARRY BALDWIN

${ }^{24}$ It is here worth noticing Julian, Or. VIII $245 \mathrm{c}$, where he says that Carthage avropro. Since this occurs in the context of Africanus sending Laelius home to Rome with the good news, the reference should be to the capture of New Carthage in Spain, as recounted in Livy (XXVII 7) and Polybius (X 19,8). Although New Carthage might be referred to as Carthage for short. Julian links the city's fall with "that of all Africa", making it pretty clear that he had confused the two events, albeit there is no note on the passage in the Loeb of W. C. Wright. Neither New Carthage nor Carthage proper were destroyed in the Second Punic War; Julian's compound verb is as diverse in meaning as Lucian's. 